\title{
Drug disposal: knowledge and practice among Pharmacy students in Brazil
}

\author{
Descarte de medicamentos: conhecimento e prática \\ de estudantes de farmácia no Brasil
}

Recebido em: 21/03/2019

Aceito em: 20/05/2019

\author{
Gustavo Freitas de Sousa VIANA; Geilson Lessa de MAGALHÃES; \\ Eulália Heleodora Santana Martins dos SANTOS \\ Centro Universitário FG-UniFG. Av. Pedro Felipe Duarte, 4911, \\ São Sebastião, CEP: 46430-000. Guanambi, BA, Brasil. \\ E-mail:vianagustavo2@gmail.com
}

\section{ABSTRACT}

There is little information on the knowledge of pharmacy students about the correct ways for drug disposal. Thus, this study aimed to evaluate the knowledge and practice of Pharmacy students about medicines disposal. A descriptive and cross-sectional study was carried out with a questionnaire application to 182 Pharmacy students in Brazil, between October and November of 2016. Data analysis of the categorical variables were performed using descriptive statistics. The Chi-square test $\left(\mathrm{X}^{2}\right)$ was used to evaluate the possible differences in the frequency between the form of medication discard according to dichotomous variables. Sixty-four point eight per cent of the students reported discarding the drugs incorrectly, and $48.8 \%$ did it in the household garbage. About $32 \%$ of the interviewers believed that the dispensation of the medicines beyond the exact amount for treatment is the main reason for the leftover. The Chi-square test showed a higher correct disposal index from the $6^{\text {th }}$ to the $10^{\text {th }}$ period, compared to the $1^{\text {st }}$ to the $5^{\text {th }}$ and according to previous guidance. Of the interviews, $67.6 \%$ considered incorrect the own way of drug disposal, $63.7 \%$ suggested the exclusive collection as the correct destination, and $84.6 \%$ reported knowing the consequences of improper disposal. This study showed that the majority of pharmacy students discards the overdue and/or unused medicines in an environmentally inadequate manner, but the correct disposal is more significant with the advance of the course period.

Keywords: Drug disposal; Environmental impacts; Pharmacy students.

\section{RESUMO}

Pouco se sabe sobre o conhecimento dos estudantes de Farmácia acerca das vias corretas de se descartar medicamentos. Assim, este estudo teve como objetivo avaliar o conhecimento e a prática dos estudantes de Farmácia sobre o descarte de medicamentos. Um estudo descritivo e de corte transversal foi conduzido, com aplicação de questionário, entre 182 estudantes de Farmácia no Brasil entre Outubro e Novembro de 2016. As análises dos dados das variáveis categóricas foram realizadas usando estatística descritiva. O teste de Chi-quadrado $\left(\mathrm{X}^{2}\right)$ foi usado para avaliar a possível diferença na frequência entre as formas de descarte de medicamentos de acordo as variáveis dicotômicas. A maioria dos estudantes $(64,8 \%)$ dos estudantes afirmou descartar os medicamentos incorretamente, sendo que 48,8\% o faziam no lixo doméstico. Cerca de $32 \%$ dos entrevistados acreditavam que a dispensação dos medicamentos além da quantidade exata para o tratamento é a principal razão para a sua sobra. O teste de Chi-quadrado mostrou um maior índice de 
descarte correto entre os estudantes do $6^{\circ}$ ao $10^{\circ}$ período, se comparado ao $1^{\circ}$ ao $5^{\circ}$, e de acordo orientação prévia. Dos entrevistados, $67,6 \%$ consideraram incorreta sua via de descarte de medicamentos, 63,7\% sugeriram a coleta especial como sendo a destinação correta e 84,6\% relataram conhecer as consequências do descarte inapropriado. Este estudo mostrou que a maioria dos estudantes de farmácia descartam os medicamentos vencidos ou não utilizados por uma maneira ambientalmente inadequada, mas o descarte correto se torna mais significativo, para eles, com o avanço no período do curso.

Palavras-chave: Descarte de medicamentos; Impactos ambientais; Estudantes de farmácia.

\section{INTRODUCTION}

Prescribed drugs are used by people for many purposes and are one of the main therapeutic strategies to prevent and cure disease. Additionally, some works have shown that the prevalence of self-medication corresponds to a significant percentage among medicines users (1-3). The use of medicines may result in leftovers, and the absence of information from the population about how to proceed with these pharmaceutical products wastes can cause risks to the environment and human been (4-6). Many drugs have compounds with high potential for bioaccumulation and low biodegradability, and when deposited in the environment, can contaminate soil and water and cause effects on aquatic animals (6-8).

Some classes of drugs present greater relevance for environmental contamination by interfering directly in living systems, such as antibiotics and endocrine disruptors (6-9). Aditya and Rattan (2014) and Pinto and cols (2014) showed a predominance in the inadequate disposal of antibiotics, and the bacterial resistance is the major concern regarding the disposal of this pharmacological class $(10,11)$. Endocrine disruptors also fit in this context, and some works had demonstrated that these compounds are capable of interfering in the development and reproduction of aquatic organisms $(9,12-14)$.

The self-medication, and the ease that the consumer finds to acquire medicines result in the accumulation of these products in the residences (15). Several factors contribute to the surplus of drugs, such as the dispensing beyond the exact amount for treatment, the non-implantation of fractionation, distribution of free sample and the interruption or change in the pharmacological treatment (11,16-20). Another relevant factor that contributes to the surplus of drugs is the low level of population information on the importance of promotion, prevention and primary health care (16).

In Brazil, residues of pharmaceutical origin are regulated by the Ministry of Health and the Ministry of the Environment $(21,22)$. The National Agency for Sanitary Surveillance (Anvisa), through RDC 222/2018, refers to Health Services Waste Management and requires every generator to prepare a Health Services Waste Management Plan (22). The resolution No. 358/2005 of the National Environmental Council (CONAMA) refers to the treatment and final disposal of health care waste, aiming at the preservation of public health and the quality of the environment (21). However, the current legislation is focused on health establishments and does not guide the final consumers about drugs discard $(23,24)$.

Several studies report that most academics, including Pharmacy students, have common trash as the primary disposal site for overdue or unused drugs; and this practice is possibly associated with a lack of information in the academic world about how to proceed with these pharmaceutical residues (25-27). It is necessary for Pharmacy student to have in-depth knowledge of the correct way to dispose of drugs since such knowledge will be essential to provide safe patient guidance during their professional practice (28).

Regarding the incorrect disposal of medicines and their consequences to the environment and the population health, it is necessary to evaluate the knowledge and practice of Pharmacy students on the disposal of overdue and/or unused drugs. Also, evaluating their perception of the potential environmental effects caused by them is crucial, 
since it allows the description of their habits and the reflection on measures that can increase their professional training.

The present study aimed to evaluate the knowledge and practice among Brazilian Pharmacy students on the disposal of overdue and or unused drugs, as well as their perception of the potential environmental effects caused by them. The authors hypothesized that Pharmacy students do not have adequate knowledge about the correct way to dispose of drugs and consequently do not know the consequences that inappropriate disposal can cause on the environment, disposing of their overdue drugs improperly. It was possible to identify possible weaknesses in the teaching-learning process of the Pharmacy student and to promote interventions in teaching practices so that the future Pharmacists acquire the knowledge that allows carry out adequate orientations to the consumer, thus helping to reduce the inappropriate disposal of these products.

\section{MATERIALS AND METHODS}

A descriptive and cross-sectional study was carried out in an institution of higher education in Brazil. The target population comprised all students enrolled in the Pharmacy course $\left(1^{\text {st }}\right.$ to $10^{\text {th }}$ semester) of the institution. It was a private institution located in the interior of Bahia, and that offers the course of Pharmacy in the morning and night shifts. Some of the students both studied and had a job, and a small percentage had a connection with pharmacies (as employment or proprietary). The sample calculation was performed based on all students enrolled, assuming a sampling error of $5 \%$ and a level of significance of $95 \%$. Thus, in a population of 384 academics, the minimum representative sample consisted of 193 students.

The population interviewed in this study was randomly selected. Numbers were assigned to members of the target population and, through a non-addicted raffle conducted by the program $O$ Sorteador and available at http://www.sorteador. com.br/, the members of the sample were selected. The selected participants were invited to participate after a brief explanation about the research, its objectives and clarifications on voluntary participation.

Students of both genders were included in the research, over 18 years old, regularly enrolled in the Pharmacy course of the institution and who agreed to voluntarily participate in the research after signing the Informed Consent Term. Were excluded the two students, that declared themselves to be embarrassed in responding to the questionnaire. Those that do not agree to sign in the Informed Consent Term, those who had the interview interrupted due to discomfort and those that were not located after three attempts, also were excluded.

Data collection occurred between October and November 2016. The interviews were carried out at the institution and a questionnaire prepared by the researchers was used as of data collection instrument. The questionnaire comprised of 14 questions, including demographic data and aspects related to the disposal of medicines. After previous scheduling, the application of the questionnaire occurred individually to each student, respecting the ethical precepts of secrecy and privacy.

After collection, the data were organized, tabulated and discussed. Data analyzes of the categorical variables were performed using descriptive statistics. The Chi-square test $\left(\mathrm{X}^{2}\right)$ was used to evaluate the possible differences in the frequency between the form of medication discard according to dichotomous variables (gender, the period of the course - i.e., $1^{\text {st }}$ to $5^{\text {th }}$ semester and $6^{\text {th }}$ to $10^{\text {th }}$, and if the subject had received previous advice on drug disposal). Statistical analyzes were done using the SPSS version 20 software, and the significance level accepted in all tests was $\mathrm{p}<0.05$.

According to Resolution 466/2012 of the National Health Council, the project was submitted and approved by the Research Ethics Committee via Brazil Platform (protocol no: 1.787.100), since this research involves human participation.

\section{RESULTS AND DISCUSSION}

In the present study, $182(94.3 \%)$ of the 193 students randomly selected according to established by methodological procedures, were 
evaluated. The 11 students needed to reach $100 \%$ of the sample number were not evaluated due to absence in the classroom after three attempts to search (10 students) or refusal to participate in the research (one student).
Table 1 shows the demographic characteristics of the students included in the study. A predominance of self-denominated brown $(56.6 \%)$ and females (71.4\%), aged 18-50 years. An average of 25.1 years was observed.

Table 1. Demographic characteristics Pharmacy students from a Brazilian College (2016) (n=182).

\begin{tabular}{|c|c|c|c|}
\hline & ariables & $\mathrm{N}$ & $\%$ \\
\hline \multicolumn{4}{|c|}{ Gender } \\
\hline Women & & 130 & 71.4 \\
\hline Men & & 52 & 28.6 \\
\hline \multicolumn{4}{|c|}{ Ethnicity } \\
\hline Brown & & 103 & $56.6 .$. \\
\hline White & & 61 & 33.5 \\
\hline Black & & 14 & 7.7 \\
\hline Others & & 4 & 2.2 \\
\hline \multicolumn{4}{|c|}{ Age } \\
\hline & Average & Minimum & Maximum \\
\hline & 25.1 & 18 & 50 \\
\hline
\end{tabular}

The main reasons, related by students, for not using the medicine in the total doses were medication dispensation went beyond the exact amount for the treatment $(31.9 \%)$, interruption or change in treatment $(27.5 \%)$, non-implantation of drug fractionation by the pharmaceutical chain $(15.9 \%)$, presentations not consistent with treatment duration $(12.1 \%)$, and receiving free samples (6.6\%) (Figure 1).

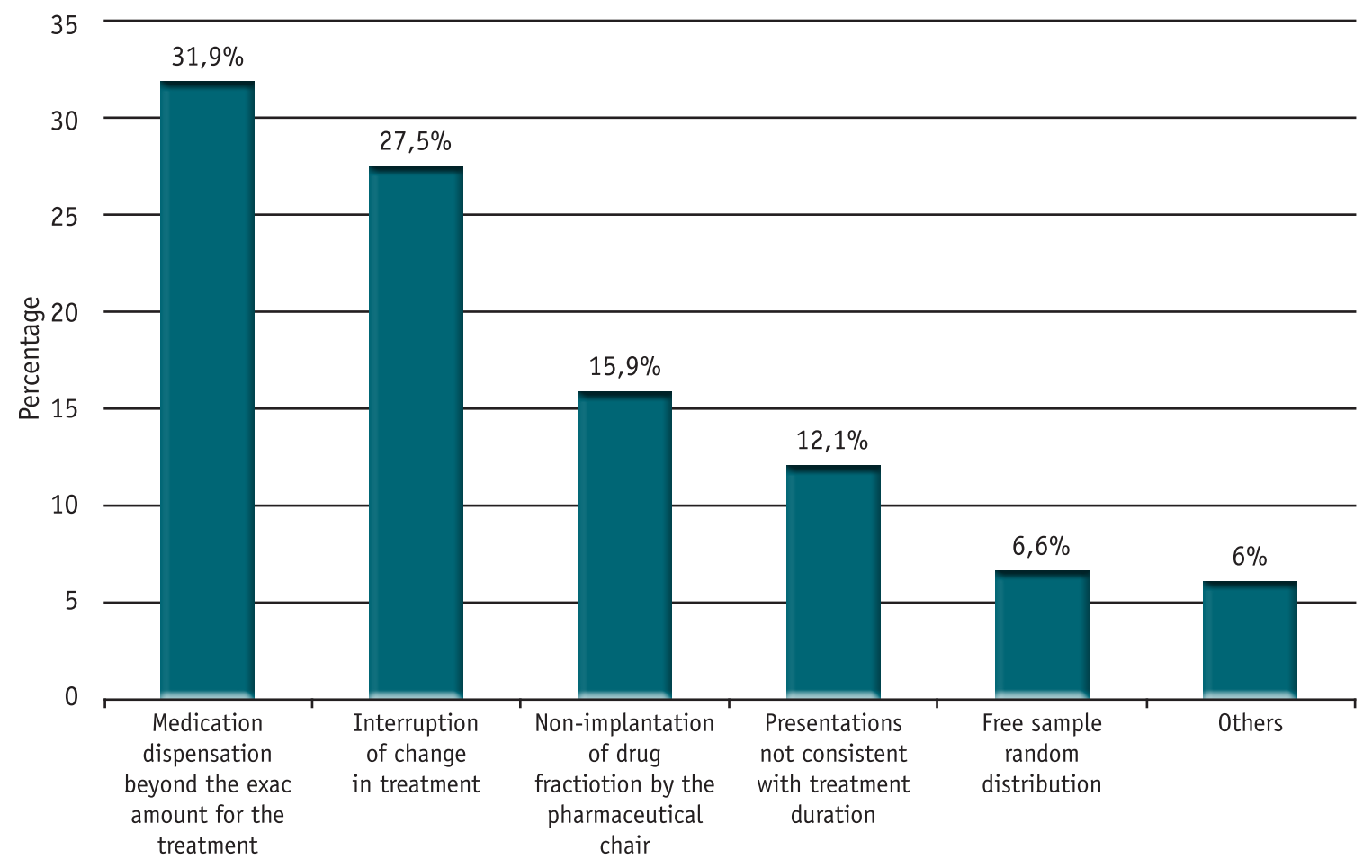

Figure 1. Reasons, according Pharmacy students from a Brazilian College (2016), for the use of the incomplete medicines doses $(n=182)$. 
The practice and attitudes adopted by students regarding the disposal of overdue and/or unused drugs can be observed in Table 2. The majority of the 182 interviewees discarded the expired or unused drugs by an environmentally incorrect way. This amount corresponds to approximately $65 \%$ of all interviewees, and the environmentally incorrect ways include the household garbage, wasteland, sink and toilet.

Table 2. Places to discard expired and/or unused medicines, according Pharmacy students from a Brazilian College (2016) $(\mathrm{n}=182)$.

\begin{tabular}{|l|c|c|}
\hline \multicolumn{1}{c|}{ Ways to discard medications } & N & (\%) \\
\hline Household garbage & 88 & 48.4 \\
\hline Return to the pharmacy or health institution & 42 & 23.1 \\
\hline Toilet & 25 & 13.7 \\
\hline Keeps saved & 15 & 8.2 \\
\hline Wasteland & 4 & 2.2 \\
\hline Sink & 1 & 0.5 \\
\hline Others & 7 & 3.8 \\
\hline
\end{tabular}

In the present study, $43.4 \%$ of the students declared that, never had received any guidance regarding the correct disposal of drugs, but $63.2 \%$ of students said that knew about the correct destination of overdue or unused drugs. However, when asked how to dispose their overdue and/or unused medicines, most of them (55.6\%) reported disposing incorrectly (household garbage, toilet, wasteland and sink).

To verify the existence of a possible difference in the frequency between the method of discarding drugs according to gender, the period of the course (i.e., $1^{\text {st }}$ to $5^{\text {th }}$ semester and $6^{\text {th }}$ to $10^{\text {th }}$ semester) and the fact that received prior guidance on drug disposal, the $X^{2}$ test was performed (Table 3). The drug discard methods were dichotomized as correct and incorrect disposal, not including, in the analyzes, the students who reported no previous discard of overdue and/or unused drugs.

Table 3. Forms of drug disposal, by Pharmacy students from a Brazilian College (2016), according to dichotomous variables $(n=160)$

\begin{tabular}{|c|c|c|c|c|c|c|}
\hline & \multicolumn{4}{|c|}{ Correct disposal } & \multirow[t]{3}{*}{$\mathrm{X}^{2}$} & \multirow[t]{3}{*}{ p-value } \\
\hline & \multicolumn{2}{|c|}{ Yes } & \multicolumn{2}{|c|}{ No } & & \\
\hline & N & $\%$ & N & $\%$ & & \\
\hline Gender & 42 & & 118 & & 2.087 & 0.149 \\
\hline $\begin{array}{l}\text { Male } \\
\text { Female }\end{array}$ & $\begin{array}{l}16 \\
26\end{array}$ & $\begin{array}{l}38.1 \\
61.9\end{array}$ & $\begin{array}{l}31 \\
87\end{array}$ & $\begin{array}{l}26.3 \\
73.7\end{array}$ & & \\
\hline Course progression & 42 & & 118 & & 7.160 & 0.007 \\
\hline $\begin{array}{l}1 \text { st to } 5 \text { th semester } \\
6 \text { th to } 10 \text { th semester }\end{array}$ & $\begin{array}{l}12 \\
30\end{array}$ & $\begin{array}{l}28.6 \\
71.4\end{array}$ & $\begin{array}{l}62 \\
56\end{array}$ & $\begin{array}{l}52.5 \\
47.5\end{array}$ & & \\
\hline Prior guidance on drug disposal & 42 & & 118 & & 14.202 & $<0.001$ \\
\hline $\begin{array}{l}\text { Yes } \\
\text { No }\end{array}$ & $\begin{array}{c}35 \\
7\end{array}$ & $\begin{array}{l}83.3 \\
16.7\end{array}$ & $\begin{array}{l}59 \\
59\end{array}$ & $\begin{array}{l}50.0 \\
50.0\end{array}$ & & \\
\hline
\end{tabular}

There was no significance difference in the correct disposal of medications according to gender $\left(X^{2}=2.087, \mathrm{p}=0.149 ; \mathrm{n}=160\right)$, but there was a significant difference according to the course period $\left(X^{2}=7.160, \mathrm{p}=0.007, \mathrm{n}=160\right)$. There was also a significant difference between correct disposal of medications according to prior guidance on drug disposal $\left(X^{2}=14.202, \mathrm{p}<0.001 ; \mathrm{n}=160\right)$. 
Among 182 students, 67.6\% considered incorrect their form of discard to overdue or unused medications, $26.4 \%$ considered correct and only $6 \%$ reported not knowing. Additionally, the present study showed that $63.7 \%$ of students considered the special collection as the correct destination for the expired and unused medicines, $2.2 \%$ considered it to be recycling, $1.6 \%$ believed that they should burn or incinerate in their own residence, and $0.5 \%$ believed that other means are the proper destination.

When evaluating the knowledge of Pharmacy students regarding the possible consequences of improper drug disposal, 84.6\% reported knowing the consequences of undue discard, while $15.4 \%$ did not know about it. In another question, that evaluated the possible consequences related to the undue disposal of medicines, $69.5 \%$ of interviewed reported soil and water contamination as main consequence for this act. Twenty-four percent claimed to know about the possibility of intoxication of worker related to waste collection (for example street-sweeper), 5.2\% reported the possibility to increase the microrganisms resistance to medications and only $1.3 \%$ cited food contamination (Figure 2).

The main findings of this study include the identifications of the reasons related by students for not using the drug complete number of doses, the practice and attitudes adopted by students regarding the drug disposal and the influence of the course period for the correct drug disposal by Pharmacy students. Many of the students reported to have the proper knowledge about the correct way to dispose of overdue or unused drugs, probably due to this content was addressed in required courses of the syllabus of students, such as Pharmaceutical Services and Biosecurity.

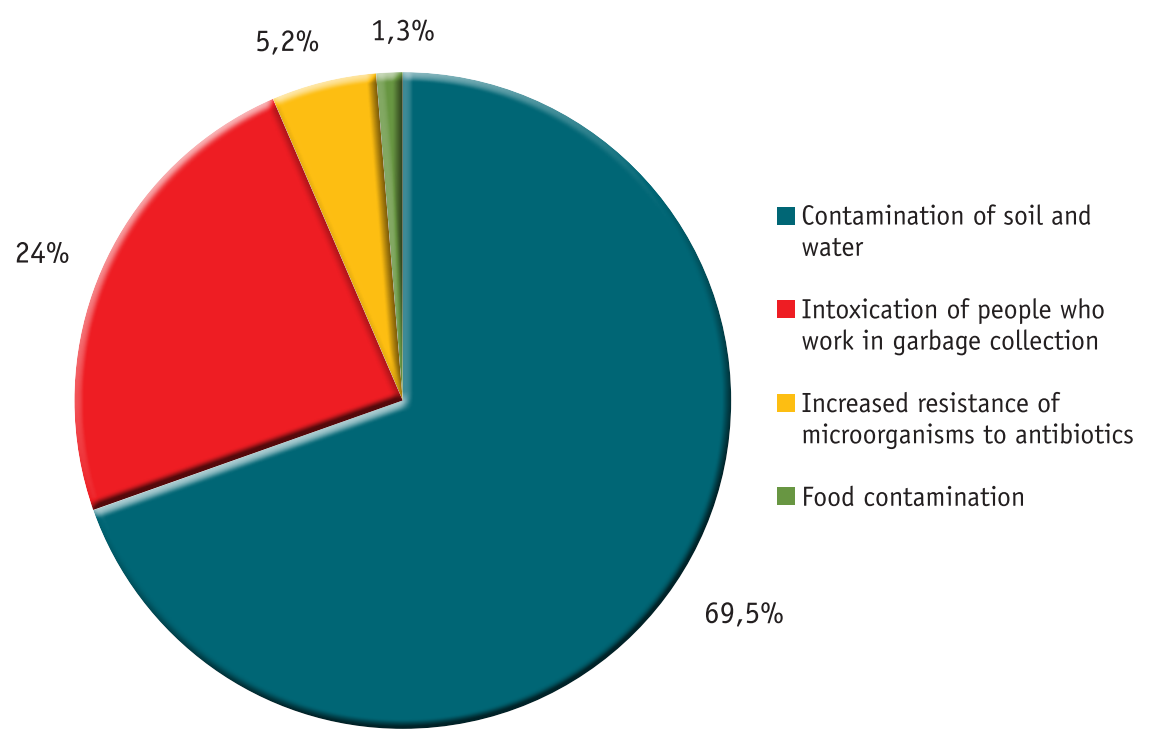

Figure 2. Consequences of incorrect drug disposal, according Pharmacy students from a Brazilian College (2016) ( $n=154)$.

According to the National Curriculum Guidelines for Undergraduate Course in Pharmacy in Brazil (established by Resolution CNE/CES n ${ }^{\circ} 6$ of 2017) (29), different structured strategies in the axes of health care, technology and innovation in health and health management can be adopted in order to develop competencies related to this theme. For this, actions aimed at guiding about the rational use of drugs and understanding the organization of services and Health Systems, in terms of pharmaceutical services, can be strategies to develop students' skills and abilities related to drug disposal.

The dispensation of the drug in addition to the exact amount for treatment, interruption or change of treatment and non-implantation of the fractionation of drugs by the pharmaceutical chain were the most prevalent causes that contributed 
to the leftover of drugs in the studied population. A study carried out with the general population accompanied by the Family Health Strategy in Ibiá, MG, Brazil, presented similar results (30) state of Minas Gerais. The purpose was to describe users' characteristics, storage conditions, therapeutic classes and pharmaceutical forms, the origin of the drugs, as well as the cost of the drugs provided by the Public Health System. A total number of 285 households were visited from July to September 2004. It was verified that the average number of drugs per household was 8.4 and that $93.5 \%$ of the surveyed families had at least one sort of drug in stock. The most stored drugs were: analgesics (11.15\%).

Dispensing of the drug beyond the exact amount for treatment may occur due to incomplete or incorrect prescription, failure to confer prescription at the time of medicines dispensing, and errors by the dispenser (31). It is important to emphasize that, although there are no flaws such as those mentioned previously, there is a possibility of non-adherence to the treatment by the patient and if this occurs, the unused medication will also be present $(16,24)$. The secondary aim was to measure the effect of a behavioral intervention (informing patients of a pharmacy-based opioid disposal program. The fractionation of medicines for dispensing in customized doses, for example, is economically effective and, consequently, can reduce the remaining pharmaceutical products amount (32).

Regardless of the cause, the presence of unused drugs at home may be a potential source of inappropriate disposal and, consequently, environmental contamination, since the majority of the studied population discarded the expired or unused drugs by an environmentally incorrect way (Table 2), and it is corroborated by literature $(11,25,26,28)$ attitudes and behaviours of medication storage and self-medication amongst female students at Universiti Sains Malaysia (USM).

Incorrect disposal of medicines is a dangerous practice because drug residues have active components with high potential for bioaccumulation and low biodegradability (33). When incorrectly disposed, especially in the household garbage or sewage network, can contaminate the soil and water, causing damage to the environment and becoming a public health problem $(6,18,34)$. Moreover, in many Brazilian cities, garbage is still discarded in the environment, making it possible, for garbage collectors, to get access to these drugs, making their consumption inappropriate (11).

Surprisingly, more than $23 \%$ of interviewed said that returned the unused and expired medications to the pharmacy or health institution for correct disposal, differently from those reported by literature $(26,28,35)$. Bashaar and cols $(2017)$, for example, demonstrated that only $7.3 \%$ of the interviewed return their expired medicines to the medical store (35). In the present study, the high percentage of returned medications to health institution can be justified by the fact that many students reported spontaneously to work in pharmacies or drugstore, leading their unused medications to be discarded in the workplace.

Results found by other authors differ from the presented results and are largely discrepant with each other. A study showed that only $2.8 \%$ of Pharmacy students returned medications to health institution (28), similar results described in Lebanon with the general population, where 3.6\%, $1.5 \%$ and $0.7 \%$ of the studied population related to return solids, liquids and creams medications, respectively, to the pharmacy (36). However, Piveta and cols (2015) showed that approximately $37 \%$ of Pharmacy students discarded the pharmaceutical residues correctly (27).

The dissemination of information is one of the best ways to inform how to dispose of expired drugs and avoid possible environmental contamination due to inappropriate disposal. The lack of this knowledge is still a significant factor among students and the general population. In the present study, $43.4 \%$ of the students declared that at no time did they receive any guidance regarding the correct disposal of drugs. Studies with the general population showed that over than $75 \%$ of the people never received any information on drug disposal $(15,28)$, demonstrating that the lack of divulgation of the theme is still quite significant. Public education actions on safe drug 
disposal are necessary, and Pharmacy students have produced positive outcomes toward reducing this environmental and potential public health risk by intervention actions (37), but still, there is need to acquire such knowledge during academic training.

It is important to recognize possible weaknesses in the teaching-learning process regarding the drug disposal after all a significant percentage of students declared that at no time did they receive any guidance regarding the correct disposal of drugs. Interventions in teaching practices should be done, so that the future pharmacists will acquire the knowledge carry out adequate orientations to the consumer of drugs, helping to reduce the inappropriate disposal of these pharmaceutical products.

An interesting result was observed: $63.2 \%$ of the students said they had the knowledge about the correct destination of overdue or unused drugs, but when asked how to dispose of the overdue and/or unused drugs, 55.6\% reported an incorrectly disposing of (household garbage, toilet, wasteland and sink). Apparently, these results are controversial, but similar results were observed by Piveta and cols (2015): 51.1\% of the students said they knew the appropriate places to dispose of drugs, but only $40.6 \%$ of them did it correctly (27). This behaviour is worrisome since these are future Health professionals with direct contact with the user of medications and, therefore, should be able to inform and aware the consumer about the appropriate conduct in cases of surplus and/or nonuse of this pharmaceutical products, serving as a model for proper practice.

As can be seen in Table 3, the chi-square analysis showed a significant difference in the correct drug disposal according to the course period. This difference may be associated with an improvement in student knowledge with the progress of the syllabus because the specific disciplines that approach the subject of drug disposal are more concentrated in the second half of the course. Previous guidance on drug disposal also appears to be a relevant variable that favours the correct disposal of these pharmaceutical products, corroborating the need to optimize
Pharmacy students training to be professionals able to spread the practice of correct drug disposal for the population.

The present study showed an awareness of the Pharmacy students about drug discard ways; most of them considered the way they practice to be incorrect, which is corroborated by other authors $(34,38)$. Although the majority of students believed that the special collection is the appropriate destination for these medicines, the current legislation in Brazil is intended only for health institutions and requires that each generator should prepare a Health Management Waste Plan, and the waste must receive a safe destination $(21,22)$. However, there is a gap in the disposal of pharmaceutical residues of domestic origin; there is still no specific selective collection for medicines in Brazil. The general population, therefore, has no alternative about the correct destination that should be given to the drugs that make up household stocks (39).

A study carried out in the general population in Kabul showed that $98 \%$ of respondents said that improper disposal of unused and expired medicines could affect the environment and health (35). However, many people use the inadequate method for lack of choice (34). Several authors had demonstrated that environmental contamination is an important consequence provided by improper disposal of medicines $(33,40-42)$. The present data corroborate the literature since the studied population reported that inappropriate disposal might result in critical problems, as soil and water contamination.

According to Ribeiro and Binsfeld (2013), overdue drugs are waste that poses a risk to the environment and public health because they are capable of contaminating soil and water (39). The incorrect disposal can also facilitate access and use by people who work in garbage collection, resulting in damage to their health (11).

This study evidenced that most of the Pharmacy students had an environmental conscience and affirmed that the undue discarding could lead to environmental problems, mainly soil and water contamination. This has been a major concern in the context of environmental contamination, and some studies have suggested methods to destroy 
or remove pharmaceutical waste minimizing the environmental damage that may arise due to inappropriate disposal of medicines $(43,44)$.

\section{CONCLUSION}

The present study evidenced that the majority of the pharmacy students discards the overdue and/ or unused drugs by an environmentally inadequate manner. However, the academic community reported to be aware of the main environmental problems caused by inappropriate disposal, but they do it incorrectly. Probably it is caused due to lack of options for disposal since there is no formal orientation in Brazil, by the competent institutions, about the correct disposal of overdue and/or unused drugs at the household level.

It is necessary for Pharmacy students to acquire this knowledge and practice during undergraduate education, and higher education institutions should be able to pass on knowledge and encourage attitudes that may help them to be prepared to play their role in society. In this study, it was observed that this is happening with the evaluated Pharmacy students, those on the most advanced semesters had more knowledge of the correct drugs disposal. It is suggested, however, that the topic should also be approached by undergraduate courses in Pharmacy in the initial periods, in addition to the implementation of extension projects involving these academics. Moreover, it is suggested the implementation of public policies that provide guidelines and conditions to the population so that their overdue or unused drugs are correctly discarded.

One limitation of the present study was to not predict other numbers for refusal or losses of randomly selected students. Thus, although the sample of this study is representative, but not statistically significant, the results obtained cannot be broadly extrapolated to national reality, since this research was carried out in a single higher education institution and did not consider the differences between institutions.

\section{REFERENCES}

1 Jafari F, Khatony A, Rahmani E. Prevalence of selfmedication among the elderly in Kermanshah-Iran. Glob J Health Sci. 2015;7(2):360-5. DOI: 10.5539/gjhs. $\mathrm{v} 7 \mathrm{n} 2 \mathrm{p} 360$

2 Jerez-Roig J, Medeiros LFB, Silva VAB, Bezerra CLPAM, Cavalcante LAR, Piuvezam G, et al. Prevalence of self-medication and associated factors in an elderly population: a systematic review. Drugs Aging. 2014;31(12):883-96. DOI: 10.1007/s40266-014-0217-X

3 Pons ES, Knauth DR, Vigo Á. Predisposing factors to the practice of self- medication in Brazil: Results from the National Survey on Access, Use and Promotion of Rational Use of Medicines (PNAUM). PLoS One. 2017;1-12. DOI: 10.1371/journal.pone.0189098

4 Buswell BR. Pharmaceuticals and personal care products in an effluent-dominated stream: seasonal variability and downstream fate (master's dissertation). Logan: Utah State University; 2017.85 p.

5 Gasparini, Joice do Carmo; Gasparini, André Renah; Frigieri MC. Estudo do descarte de medicamentos e consciência ambiental no município de Catanduva-SP. Ciência Tecnol FATEC-JB. 2011;2(1):38-51.
6 Ueda J, Tavernaro R, Marostega V, Wesley P. Impacto ambiental do descarte de fármacos e estudo da conscientização da população a respeito do problema. Ciênc Ambient. 2009;5:1-6.

7 Peters JR, Granek EF, Rivera CE, Rollins M. Prozac in the water: chronic fluoxetine exposure and predation risk interact to shape behaviors in an estuarine crab. Ecol Evol. 2017;(August):1-11. DOI: 10.1002/ece3.3453

8 Souder JP, Gorelick DA. Assaying uptake of endocrine disruptor compounds in zebrafish embryos and larvae. Comp Biochem Physiol Toxicol Pharmacol. 2017;208:105-13. DOI: 10.1016/j.cbpc.2017.09.007

9 Länge R, Hutchinson TH, Croudace CP, Siegmund F, Schweinfurth H, Hampe P, et al. Effects of the synthetic estrogen $17 \alpha$-ethinylestradiol on the life-cycle of the fathead minnow (Pimephales promelas). Environ Toxicol Chem. 2001;20(6):1216-1227. DOI: 10.1002/ etc. 5620200610

10 Aditya S, Rattan A. Minimizing pharmaceutical waste: The role of the pharmacist. J Young Pharm. 2014;6(3):1419. DOI: $10.5530 /$ jyp. 2014.3 .3 
11 Pinto GMF, Silva KR, Pereira RFAB, Sampaio SI. Estudo do descarte residencial de medicamentos vencidos na região de Paulínia (SP), Brasil. Eng Sanit e Ambient. 2014;19(3):219-224. DOI: 10.1590/S141341522014019000000472

12 Geraudie P, Gerbron M, Minier C. Endocrine disruption effects in male and intersex roach (Rutilus rutilus L.) from French rivers: An integrative approach based on subcellular to individual responses. Comp Biochem Physiol Part - B Biochem Mol Biol. 2017;211:29-36. DOI: 10.1016/j.cbpb.2017.05.006

13 Luzio A, Santos D, Fontaínhas-Fernandes AA, Monteiro SM, Coimbra AM. Effects of $17 \alpha$-ethinylestradiol at different water temperatures on zebrafish sex differentiation and gonad development. Aquat Toxicol. 2016;174:22-35. DOI: 10.1016/j. aquatox.2016.02.003

14 Tyler CR, Lange A, Paull GC, Katsu Y, Iguchi T. The roach (Rutilus rutilus) as a sentinel for assessing endrocrine disruption. Environ Siences. 2007;14(5):235-253.

15 Bueno CS, Weber D, Oliveira KR. Farmácia caseira e descarte de medicamentos no bairro Luiz Fogliatto do município de Ijuí - RS. Rev Ciencias Farm Basica e Apl. 2009;30(2):203-210.

16 Maughan BC, Hersh E V., Shofer FS, Wanner KJ, Archer E, Carrasco LR, et al. Unused opioid analgesics and drug disposal following outpatient dental surgery: a randomized controlled trial. Drug Alcohol Depend. 2016;168:328 334. DOI: $10.1016 /$ j.drugalcdep.2016.08.016

17 Mirza N, Ganguly B. Utilization of medicines available at home by general population of rural and urban set up of Western India. J Clin Diagnostic Res. 2016;10(8):FC05FC09. DOI: $10.7860 / J C D R / 2016 / 20600.8298$

18 Pereira AL, Barros RTV, Pereira SR. Pharmacopollution and Household Waste Medicine (HWM): how reverse logistics is environmentally important to Brazil. Environ Sci Pollut Res. 2017;24(31):24061-24075. DOI: 10.1007/s11356-017-0097-9

19 Ruhoy IS, Daughton CG. Beyond the medicine cabinet: an analysis of where and why medications accumulate. Environ Int. 2008;34(8):1157-1169. DOI: 10.1016/j. envint.2008.05.002

20 Zorpas AA, Dimitriou M, Voukkali I. Disposal of household pharmaceuticals in insular communities: social attitude, behaviour evaluation and prevention activities. Environ Sci Pollut Res. 2017;1-11. DOI: 10.1007/s11356-017-9551-y

21 BRASIL. Conselho Nacional do Meio Ambiente. Resolução CONAMA n ${ }^{\circ}$ 358, de 29 de abril de 2005. Dispõe sobre o tratamento e a disposição final dos resíduos dos serviços de saúde e dá outras providências. Diário Oficial da União, $\mathrm{n}^{\circ} 84$, de 4 de maio de 2005 , Seção 1. p. 63-65.
22 BRASIL. Agência Nacional de Vigilância Sanitária. Resolução da diretoria colegiada - RDC 222, de 28 de março de 2018. 2018.

23 Vaz K, Freitas M, Cirqueira J. Investigação sobre a forma de descarte de medicamentos vencidos. Cenarium Pharm. 2011;4(4):25.

24 Vieira Alvarenga LS, Nicoletti MA. Descarte doméstico de medicamentos e algumas considerações sobre o impacto ambiental decorrente. Saúde-UNG. 2010;4(3):34-39.

25 Ali SE, Ibrahim MIM, Palaian S. Medication storage and self-medication behaviour amongst female students in Malaysia. Pharm Pract. 2010;8(4):226-232. DOI: 10.4321/S1886-36552010000400004

26 Auta A, Banwat SB, Sariem CN, Shalkur D, Nasara B, Atuluku MO. Medicines in pharmacy students' residence self-medication practices. J Young Pharm. 2012;4(2):119-123. DOI: 10.4103/0975-1483.96627

27 Piveta L., Silva LB, Guidoni CM, Girotto E. Armazenamento e descarte de medicamentos por acadêmicos da área da saúde de uma universidade pública paranaense. Semin Cienc Biol Saude. 2015;36(1):55-66. DOI: $10.5433 / 1679-0367.201 v 36 n 1 p 55$

28 Silva NR, Abjaude SAR, Rascado RR. Atitudes de usuários de medicamentos do Sistema Único de Saúde, estudantes de farmácia e farmacêuticos frente ao armazenamento e descarte de medicamentos. Rev Ciencias Farm Basica e Apl. 2014;35(2):317-323.

29 BRASIL. Ministério da Educação. Resolução nº 6, de 19 de Outubro de 2017. Institui as Diretrizes Curriculares Nacionais do Curso de Graduação em Farmácia e dá outras providências. Diário Oficial da União, 18 de outubro de 2017, Seção 1, p. 42.

30 Ribeiro MÂ, Heineck I. Estoque domiciliar de medicamentos na comunidade ibiaense acompanhada pelo programa saúde da família, em Ibiá-MG, Brasil. Saúde Soc. 2010;19(3):653-663.

31 Eickhoff P, Heineck I, Seixas LJ. Gerenciamento e destinação final de medicamentos : uma discussão sobre o problema. Rev Bras Farm. 2009;90(1):64-68.

32 Romero JP, Romero MP, Hermida JRV, Souto MT. Evaluación del programa piloto de dispensación de medicamentos en dosis personalizada en Galicia. Gac Sanit. 2007;21(1):18-24. DOI: 10.1157/13099115

33 Lees K, Fitzsimons M, Snape J, Tappin A, Comber S. Pharmaceuticals in soils of lower income countries: Physico-chemical fate and risks from wastewater irrigation. Environ Int. 2016;94:712-723. DOI: 10.1016/j.envint.2016.06.018

34 Hoppe TRG, Araújo LEB. Contaminação do meio ambiente pelo descarte inadequado de medicamentos vencidos ou não utilizados. Monogr Ambient. 2012;6(6):1248-1262. 
35 Bashaar M, Thawani V, Hassali MA, Saleem F. Disposal practices of unused and expired pharmaceuticals among general public in Kabul. BMC Public Health. 2017;17(1):45. DOI: 10.1186/s12889-016-3975-z

36 Massoud MA, Chami G, Al-Hindi M, Alameddine I. Assessment of household disposal of pharmaceuticals in Lebanon: management options to protect water quality and public health. Environ Manage. 2016;57(5):11251137. DOI: $10.1007 / \mathrm{s} 00267-016-0666-6$

37 Abrons J, Vadala T, Miller S, Cerulli J. Encouraging safe medication disposal through student pharmacist intervention. J Am Pharm Assoc. 2010;50(2):169-173. DOI: 10.1331/JAPhA.2010.09208

38 Silva BR. Descarte residencial de medicamentos e sensibilização sobre impacto ambiental dos acadêmicos de biologia (trabalho de conclusão de curso). Patos: Universidade Federal de Campina Grande; 2015. 33 p.

39 Ribeiro; MA, Binsfeld PC. Descarte de medicamentos vencidos ou não utilizados: riscos e avanços recentes (trabalho de conclusão de curso). Goiania: Pontifícia Universidade Católica de Goiás; 2013. 17 p.
40 Bound JP, Voulvoulis N. Household disposal of pharmaceuticals as a pathway for aquatic contamination in the United Kingdom. Environ Health Perspect. 2005;113(12):1705-1711. DOI: 10.1289/ehp. 8315

41 Gamarra JS, Godoi AFL, de Vasconcelos EC, de Souza KMT, Ribas de Oliveira CM. Environmental Risk Assessment (ERA) of diclofenac and ibuprofen: A public health perspective. Chemosphere. 2015;120:462-469. DOI: 10.1016/j.chemosphere.2014.08.020

42 Janecko N, Pokludova L, Blahova J, Svobodova Z, Literak I. Implications of fluoroquinolone contamination for the aquatic environment-A review. Environ Toxicol Chem. 2016;35(11):2647-2656. DOI: 10.1002/etc.3552

43 Aquino SF, Brandt EMF, Chernicharo CAL. Remoção de fármacos e desreguladores endócrinos em estações de tratamento de esgoto: revisão da literatura. Rev Eng Sanit Amb. 2013;18(3):187-204. DOI: 10.1590/S141341522013000300002

44 Bean TG, Bergstrom E, Thomas-Oates J, Wolff A, Bartl P, Eaton B, et al. Evaluation of a novel approach for reducing emissions of pharmaceuticals to the environment. Environ Manage. 2016;58(4):707-720. DOI: $10.1007 / \mathrm{s} 00267-016-0728-9$ 